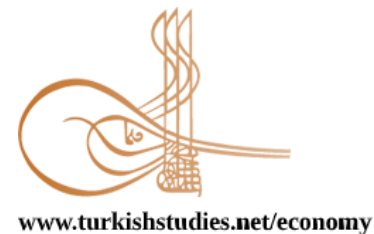

Turkish Studies - Economics, Finance, Politics

\title{
24 Haziran 2018 Seçimlerinde Adalet ve Kalkınma Partisinin Kullandığı Zümrüd-ü Anka Siyasal Reklamının Analizi
}

Analysis of Zümrüd-ü Anka Political Advertisement Used By Adalet and Kalkanma Party in June 24 June 2018 Elections

\author{
İhsan Karlı ${ }^{*}$ - Özlem Özbay ${ }^{* *}$
}

\begin{abstract}
Political advertising activities, which are included in the communication strategies formed during the political campaign processes, aim to influence the attitudes and behaviours of the voters and to direct the voters within their own interests. Political parties aim to have positive effects on the electorate with different contents, themes, visuals and voice usage. In order to realize these aims one of their activities is political advertising activities. Political advertising is also closely related to cultural values. Culture expresses a community's totality of beliefs, including language, values and beliefs, legends and myths. Therefore, the cultural elements of society should be taken into consideration in the preparation of political advertisements. Because an advertising film addressing cultural values is more likely to influence the target audience. Therefore, Zümrüd-ü Anka advertisement which was prepared for the June 24, 2018 parliamentary general elections of the Justice and Development Party, the use of cultural dimensions of Hofstede 'Power range', 'individualism / collectivism', 'masculinity / femininity', 'avoidance of uncertainty', 'pragmatism / normativism' and 'long-term - short-term spread' were analyzed according to the frequency of six dimensions. As a result of the analysis, it was found that the Justice and Development Party addressed all elements of Hofstede's six cultural dimensions, in particular the cultural dimensions of power distance and avoidance of uncertainty, addressing the sense of belonging and promising a better future for all. As it is seen in the result of the research, political parties aim to protect the cultural values of the voters and address these cultural values in order to create the desired effect on the voters.
\end{abstract}

Structured Abstract: Introduction and Purpose of the Study: Election advertisements were analyzed within the framework of Hofstede's cultural dimensions and it was aimed to determine whether or not the existence of cultural dimensions was emphasized in commercial films.

\footnotetext{
* Doç. Dr. Kocaeli Üniversitesi İletişim Fakültesi, Gazetecilik Bölümü

Assoc.Prof., Kocaeli University, Faculty of Communication, Journalism Department ORCID 0000-0002-3099-4865

ihsankarli@yahoo.com

*** Öğrenci, Kocaeli Üniversitesi, İletişim Fakültesi, Halkla İlişkiler ve Tanıtım Bölümü

Student, Kocaeli University, Faculty of Communication, Public Relations and Publicity Department

ORCID 0000-0002-8475-7654

ozlemozbay94@gmail.com

Cite as/ Atıf: Karlı, İ, \& Özbay Ö. (2020). 24 Haziran 2018 Seçimlerinde Adalet ve Kalkınma Partisinin kullandığ

Zümrüd-ü Anka siyasal reklamının analizi. Turkish Studies - Economy, 15(3), 1469-1483. https://dx.doi.org/10.47644/TurkishStudies.41669

Received/Geliş: 07 February/Şubat 2020

Accepted/Kabul: 20 September/Eylül 2020

Copyright (C) INTAC LTD, Turkey

Checked by plagiarism software

Published/Yayın: 25 September/Eylül 2020

CC BY-NC 4.0
} 


\section{Universe Sample and Method}

The universe of the study consists of election advertisements prepared for election periods. The advertisement film of Zümrüd-ü Anka of Justice and Development Party, which was prepared for the June 24 general elections, constitutes the sample. In order to examine the use of cultural dimensions, content analysis method was used to determine which emphasis was made on the content of each cultural dimension.

\section{Conceptual Theoretical Framework}

\section{Power range size:}

In the commercial film, it is tried to determine how the central authority is connected with the public. The willingness to voluntarily agree to the rules and instructions of the central authority is a form of positive emphasis. The fact that individuals in society accept the authority of another power of their choice to make decisions on their behalf was accepted as a positive emphasis on the existence of central authority.

Individualism / Collectivism Dimension:

It has been questioned whether political parties consider the welfare of their voters or whether the group they are in wants the welfare and peace of the family. At the same time, the place where political parties place themselves in society is important in emphasizing this cultural dimension. Emphasis on us, emphasis on togetherness and sense of gratitude in the advertisements are among the elements that emphasize this dimension.

\section{Emphasis on the cultural dimension of masculinity / femininity:}

The political party and the electorate; the discourse emphasizing the characteristics of the feminine character such as being a social individual, emphasizing cooperation, raising environmental awareness, protecting the environment and animals, giving importance to solidarity should be analyzed. Attention should be paid to the element of power in society, to war, to masculine discourses such as competition and money. In this kind of discourse existing in advertising, masculinity represents the cultural dimension.

Emphasis on the cultural dimension of avoiding uncertainty:

It was taken into consideration that the voter prefers situations in which he feels safe and knows about himself before. If the voter prefers the tried-and-tested candidate, this is considered as an indicator of the size of avoiding uncertain situations.

Pragmatism - Emphasis on the cultural dimension of social change:

When it is emphasized that social change will be positive and the studies to be carried forward will advance society, pragmatism / social change is accepted as the emphasis on cultural dimension. While this represents the cultural dimension; the existence of bright sunny days, catching the age, the increase in economic prosperity and the beauties in the future of our children are mentioned.

\section{Conclusion}

The process of political communication facilitates the identification of messages to be given if the target audience is correctly identified and sufficiently recognized. The communication strategy implemented by the Justice and Development Party with the advertisement film Zümrüd-ü Anka on the 24 June 2018 parliamentary general elections.was developed in this direction. The message to be given through the political advertising campaign was analyzed according to the cultural values of the target audience and shaped accordingly. Emphasis has been placed on the beliefs of the society, its ties from the past, its past, its values, and the position it wants to be in the future. In the advertising film analyzed according to Hofstede's table of cultural values, the highlights of each category were determined. As a result of the study, it was seen that the communication activities carried out during the political communication process were prepared considering the cultural values of the society, the elements of the culture were carefully selected, and the political discourses were prepared in this direction.

Keywords: Political Advertising, Geert Hofstede, Cultural Dimensions, Political Communication 
Öz: Siyasal kampanya süreçlerinde oluşturulan iletişim stratejileri içerisinde yer alan siyasal reklam faaliyetleri, seçmenlerin tutum ve davranışlarına etki etmeyi ve seçmenleri kendi çıkarları çerçevesinde yönlendirmeyi hedeflemektedirler. Siyasal partiler farklı içerikler, temalar, yazılı materyaller, videolar, görseller ve ses kullanımı ile seçmen kitlenin üzerinde olumlu etkiler sağlamayı amaçlamaktadır. Bu amaçlarını gerçekleştirebilmek için uyguladıkları faaliyetlerden biri de siyasal reklam uygulamalarıdır. Siyasal reklamcılık kültürel değerlerle de yakın ilişki içerisindedir. Kültür bir topluluğun dilini, değer ve inançlarını, efsanelerini ve mitlerini kapsayan inançlar toplamını ifade etmektedir. Dolayısıyla siyasal reklamların hazırlanmasında toplumun kültürel ögeleri göz önünde bulundurulmalıdır. Zira kültürel değerlere seslenen bir reklam filminin hedef kitleyi etkisi altına alması çok daha mümkündür. Dolayısıyla, Adalet ve Kalkınma Partisi'nin 24 Haziran 2018 Milletvekili Genel Seçimleri için hazırlanan 'Zümrüd-ü Anka' reklamı Geert Hofstede'nin kültürel boyutlarının kullanımı; 'güç aralığı', 'bireycilik/kolektivizm', 'erillik/dişilik', 'belirsizlikten kaçınma', 'pragmatizm /normativizm' ve 'uzun döneme - kısa döneme yayılma' şeklindeki altı boyutun sıklığına göre analiz edilmiştir. Analiz sonucunda Adalet ve Kalkınma Partisi'nin Hofstede'nin altı kültürel boyutunun tüm öğelerine seslendiği özellikle de 'güç mesafesi' ve 'belirsizlikten kaçınma' kültürel boyutlarına fazlaca vurgu yaparak aidiyet hissine seslendiği ve herkes için daha iyi bir gelecek vaat ettiği tespit edilmiştir. Araştırmanın sonucunda da görüldüğü gibi siyasal partiler seçmenlerin üzerinde istenilen etkiyi oluşturabilmek adına öncelikle seçmenin kültürel değerlerine sahip çıkmayı ve bu kültürel değerlere seslenmeyi amaçlamaktadırlar.

Anahtar Kelimeler: Siyasal Reklam, GeertHofstede, Kültürel Boyutlar, Siyasal İletişim

\section{Giriş}

Kültürün tüm ülkelere ve toplumsal değerlere göre sınıflandırılması gerektiği düşüncesi 20. yüzyılın ikinci yarısında ortaya çıkmıştır. Kültür günümüze kadar farklı boyutlar kapsamında incelenerek geliştirilmiştir. Bu boyutlar toplumların belirli sorunlarının içerisinde oluşturulmuş aynı zamanda pek çok araştırmada her bir toplum için farklı kültür değerleri olduğu düşüncesini ortaya koymuştur. $\mathrm{Bu}$ araştırmalar toplumların karakter bazındaki farklılıklarını ortaya koymayı amaçlamıştır. Bütün bu çalışmalar içinde yer edinen Geert Hofstede'nin çalışması olmuştur. Aynı zamanda sosyolog olan Geert Hofstede'nin 1980 yılından sonra yapmış olduğu ve 90 ülkeyi içine alan bir araştırmasının sonuçlarından ortaya çıkan kültürel boyutlar teorisi günümüzde oldukça önemli bir araştırma olarak kabul edilmektedir. Örgütsel ve sosyolojik içeriğe sahip pek çok araştırma bu kültürel boyutlardan ve ülkeler bazında belirlenmiş olan kültürel boyut düzeylerinden faydalanarak karşılaştırmalı sonuçlar sunmuş; bu sayede literatüre toplumlara göre kültürel farklılıklar konusunda kayda değer enformasyonlar sağlanmıştır.

Siyasal iletişim kavramı demokratikleşmeyle hayatımıza giren bir olgu olmakla beraber yöneten ve yönetilen ilişkisinin oluştuğu toplumlara dayanmaktadır. Siyasal reklamcılık kavramı geçmiş zamanlardan günümüze kadar belki de bir toplumda halkın kültürel profilini göz önüne alarak tasarlanan iletişim faaliyetlerden biri olarak hayatını sürdürmektedir. Özellikle televizyonda yayınlanan reklamlar, pek çok ülkede var olduğu gibi Türkiye'de de hedef kitleye en dolaysız yoldan iletilen mesaj ve iletileri içermesi açısından önemli iletişim araçlarındandır. Türkiye'de de televizyon izleme oranlarının yüksek olduğu bilinmekte ve televizyon izleme sürelerinin de uzun olduğu görülmektedir. Dolayısıyla da seçmene en doğru şekilde en doğru zamanda iletilmesi arzulanan mesajın televizyon kanallarındaki programlar ve televizyon reklamları aracılığıyla ulaştırılması gün geçtikçe daha kolay ve etkili bir hale gelmiştir.

Hedefte olan seçmen kitlenin siyasi tutumu ve oy verme davranışı üzerinde istenen yönde etkiyi yaratabilmek amacıyla, o toplumun değer ve karakter özelliklerine uyumlu olan reklamların yayınlanmasının, siyasi partilerin reklam kampanyalarının başarıya ulaşmaları bağlamında büyük önem taşıdığ 1 düşünülmektedir. Yapılan bu çalışma seçilen reklamlarda toplumsal boyutların ne derece dikkate alındığını irdelemektedir. Bu amaç çerçevesinde çalışmada Adalet ve Kalkınma Partisi'nin 24 Haziran genel seçimleri için hazırlanan 'Zümrüd-ü Anka' isimli reklam filmi 
incelenmiştir. Çalışma içinde söz konusu televizyon reklamlarında Hofstede tarafindan belirlemiş olan kültürel boyutların ne kadar vurgulandığı sorgulanmıştır.

Çalışmanın birinci bölümünde siyasal iletişim, siyasal reklamcılık, siyasal kültür kavramlarından ve bu kavramların birbirleriyle olan ilişkisinden, geçmiş zamandan günümüze kadar geçtikleri evrelerden bahsedilmiş; daha sonrasında ise Hofstede'nin kültürel boyutları ve bu boyutların kullanıldığı araştırmalara yer verilerek kültürün siyasal iletişime olan katkısı sunulmuştur. Çalışmanın son bölümünde çalışmanın amacı, yöntemi ve çalışmaya konu olan reklam filminin, Hofstede'nin kültürel boyutları kapsamında incelenmesiyle beraber elde edilmiş olan bulgulara yer verilmiştir. Çalışmanın sonuç bölümünde ise araştırmadan elde edilen tüm bu bilgiler ve bulgular kuramsal verilerin 1şığında yorumlanmıştır. Yapılan yorumlamaların ardından öneriler sunulmuştur.

\section{Siyasal İletişim Kavramı}

İletişim insan yaşamında çok önemli bir yere sahiptir. Toplumsal alanın hemen her yerinde iletişim kurmak zorunda kalırız. Siyasette de gerek siyaset yapanlar gerekse vatandaşlar için iletişim ve siyaset çok yakın bir ilişki içerisindedir (Tokgöz, 2008:21). Siyasal iletişim kavramının ortaya çıkması. 2. Dünya Savaşı'na kadar dayanır. Bu kavramın ilk olarak Amerika Birleşik Devletleri'nde (ABD) ortaya çıktığı bilinmektedir. Siyasal iletişim kavramı ABD'de ortaya çıktığ1 gibi gelişimini de önemli ölçüde orada gerçekleştirmiştir. 1950'li yıllara kadar siyaset ve iletişim kavramlarının altında ele alınan siyasal iletişim kavramı günümüzde yeni bir bilimsel disiplin olarak ele alınmaktadır. Siyasal iletişim "Siyasal süreçler ve iletişim süreçleri arasındaki ilişkilerin ele alındığı araştırmalardan oluşan, disiplinler arası akademik bir alan" (Mutlu, 2004:199 ) olarak tanımlanmaktadır. Siyasal iletişim sürecinde vatandaşların istek ve talepleri doğru tespit edilmelidir. Bu tespitin önemi siyasal kurumların toplumun istek ve talepleri doğrultusunda hareket etmelerine olanak sağlamaktır. Toplumun istek ve talepleri doğrultusunda hareket eden siyasal partilerin siyasal seçim sürecinde başarıya ulaşmaları daha kolay bir duruma gelmektedir.

"Siyasal aktörlerin belli ideolojik amaçları vardır. Bu ideolojik amaçlarını belli gruplara, kitlelere, ülkelere gruplara ya da bloklara kabul ettirmek, aynı zamanda gerektiğinde bu ideolojik amaçlar için harekete geçmek, uygulamaya koymak amaciyla çeşitli iletişim tür ve tekniklerini kullanmaları siyasal iletişim olarak adlandırılır" (Aziz, 2013:3). Bu şekilde yapılan siyasal iletişim tanımı ise konuya daha geniş bir açıdan bakmamızı sağlamıştır. Bu tanımdan da yola çıkarak siyasal iletişim sürecinde en önemli kriterin hedef kitlelere nasıl ulaşıldığı ve bu süreçte hangi yöntemlerin ve hangi mecraların kullanıldığıdır. "Siyasal iletişimin siyasete birçok katkısı vardır. Siyasal iletişim hem siyasette denetim ve şeffaflık sağladı̆̆ 1 , hem de siyaset yapanların, seçmenlerin düşüncelerini demokratik ikna yöntemleriyle etkilemelerine yardımcı olan bir iletişim arac1 görevi görmektedir" (Oktay, 2014:75). Oktay’ın tanımı da siyasal iletişim üzerine yapılmış diğer bir tanımdır. En genel tanımıyla toplumlardaki iletişim süreçlerinin içerisinde siyasal unsurları barındıran kısımları siyasal iletişim olarak tanımlamak mümkündür. Siyasal bir amaç çerçevesinde toplumla ilişki kurmak ve toplumun siyasi hayatı üzerinde söz sahibi olmak siyasal iletişimin önemli amaçlarındandır.

Siyasal iletişimin iki boyutu vardır. Bunlardan biri siyasal alanda faaliyet gösteren profesyonellerin amaçlarını gerçekleştirmek doğrultusunda mesleki ve teknik çalışma sahaları olarak kullandıkları bir alan; diğer boyutu ise iletişim sürecinde kullanılan siyasal söylemlerin üretimi, değişikliği, dağılımı, nerede ve ne zaman kullanılması gerektiğine ilişkin tüm sosyal ve kamusal faaliyetlerdir. Siyasal iletişim politik etkinliği arttırma işlevi nedeniyle daha çok işlevci yönleriyle ele alınır. Siyasal iletişimin işlevleri şu şekildedir:

a. Siyasi içerikli mesajların hedef kitleye aktarılması

b. Siyasi içerikli mesajların tekrarının ve kalıcılığının arttırılması

Turkish Studies - Economy, 15(3) 
c. Kaтиоуипun istek ve arzularının saptanması, karşılanması

d. İletişim sürecindeki iletilerin geri besleme takiplerinin yapılması

e. Kanaat önderlerinin belirlenmesi ve etkilenmesi

f. Gündemde kalma oranının artırılması

g. Siyasal rakiplerin iletişim faaliyetlerinin de takibinin yapılması

h. Siyasal rakiplerden avantajlı duruma geçilmesi

Siyasal iletişimin işlevleri, kamuoyu araştırmaları uygulamalarında, kitle iletişim araçları üzerinde, siyasal pazarlama ve siyasal reklamcılık gibi alanlarda daha etkili olabilmek adına gerçekleştirilir. İletişim öğeleri kullanılarak uygulanan siyasal iletişim süreci, kamuoyu hakkında 1şık olmakta kamuoyunun istekleri, beklentileri, ilgi alanları, eksikleri, değerlerinin tanımlanmasında rol oynamaktadır. Bu da siyaset bilimi ile iletişim bilimleri arasında köprü oluşmasına neden olmaktadır (Köker, 1998: 22). Siyasal iletişim olgusunun günümüzde oldukça önem kazanmasının bir nedeni ise iletişim süreçlerinin çoğu zaman olumlu sonuçlanmasıdır. Bu iletişim sürecinde kullanılan çeşitli halkla ilişkiler faaliyetleri siyasal iletişim sürecinde verilmek istenen mesajın hedef kitleye doğru ulaşmasını sağlamakta ve hedef kitlenin siyasal tutumları üzerinde etkili olması amaçlanmaktadır. Siyasal iletişim sürecinde kullanılan en etkili iletişim çalışmalarından biri de siyasal reklamcılıktır.

\section{Siyasal Reklamcılığa Bakış}

Ülkelerde siyaset olgusunun öneminin sürekli artmakta olması siyasal reklamcılık kavramının da gün geçtikçe önem kazanmasına ve teknolojiye de uyum sağlayarak hızla gelişmesine neden olmaktadır. Siyasal reklamcılık "aday ya da parti tarafindan belirli bir amaç doğrultusunda medyadan belirli bir ücret karşıllı̆ında yer ve zaman satın alınarak, seçmenlerin tutum ve davranışlarını kendi aday veya partileri hakkında etkilemek amacıyla geliştirilen mesajın kodlanması ve iletilmesi süreçleriyle ilgili bir siyasal iletişim faaliyetidir" (Uztuğ, 1999:122). Bu bağlamda adaylar ve siyasal partiler reklam mesajlarını hedef kitleye iletmede görsel işitsel araç olarak televizyondan, basılı araç olarak gazetelerden, dergilerden vs. diğer basılı materyaller olan afiş, poster, billboardlar gibi açık hava araçlarından, işitsel araç olarak da radyolardan yararlanmaktadırlar (Uztuğ, 1999:123).

Televizyonun hayatımıza girmesiyle birlikte özellikle gelişen teknoloji kitle iletişim araçlarında meydana gelen gelişmeler siyasal reklamcılıkta da hızlı bir dönüşüm ve gelişim yaşanmasını sağlamıştır. "Siyasal reklamcılığın kampanya dönemlerinde ilk kez kullanılması 1952 yılında ABD başkanlık seçimlerinde Eisenhower için hazırlanan siyasal reklamda görülmektedir" (Kılıçaslan, 2013:53). Siyaset bilimi ve iletişim alanındaki mevcut araştırmalar, genelikle protestolar ya da televizyon tartışmaları gibi siyasi olayların online öğelerini tanımlamak için, güvenilirlik, tarihçe, geçerlilik, kamuoyu yoklaması, fayda gibi dijital verileri kısmen kullanmaktadır (Schill, Kirk ve Jasperson, 2017; 12)

Türkiye'de ise siyasal reklamcılığın profesyonel anlamda ilk kez 1977 genel seçimlerinde uygulandığı bilinmektedir. Adalet Partisi (AP), yasalar gereği siyasal reklam yapılması yasak olsa bile Cen Ajans adındaki reklam ajansıyla anlaşarak, gazetelere siyasal reklam vermiştir (Tokgöz, 2010:45). Siyasal reklamcilık, 1990 yılından sonra özel televizyon kanallarının artmasıyla birlikte daha çok önem kazanmıştır. Televizyon izleme oranın gittikçe artmış olması siyasal iletişim sürecinde en etkili olan kitle iletişim aracının televizyon olmasına yol açmıştır. Bu durumda seçim dönemlerinde televizyon üzerinden hedef kitleyle iletişim kurulmasını hızlandırmıştır. Reklam filmleri hazırlanmış, açık oturumlar düzenlenmiş, miting programlarının TV'lerden yayınlanması, insanların evlerinden siyasi partilerin vaatlerine ulaşmasına olanak vermiştir. Özetle televizyon 
yayıncılığı partilerin halkla seslenmesinde önemli bir iletişim aracı olarak günümüzde de önemli bir yer edinmiştir.

Siyasal reklamcılıkta mümkün olan en kısa sürede seçmenin siyasi düşünceleri ve tutumları üzerinde etkide bulunmak amaçlanmaktadır. Siyasal reklamcılıkta kullanılan televizyon, internet, radyo, gazete billboard, afiş gibi mecraların fazlalığı verilmek istenilen mesajın hedef kitleye birçok alanda sık sık ulaşıyor olması yani mesajın tekrar edilmesi bununla beraber mesajın akılda kalınabilirliğini arttırmaktadır. Siyasal reklamcılıkta bir reklam metninin ya da reklam filminin hazırlanmasındaki temel amaç siyasal mesajın, siyasal adayın ya da siyasal partinin hedef kitle üzerindeki etkisinin arttırılmasıdır. Bu nedenle, siyasal kampanyaları anlamak, politik reklamcılığın nasıl oluşturulduğunu ve konuşlandırıldığını, teknoloji ve düzenleyici ortamdaki gelişmelerin kampanyaların seçimlerini ve doğrudan seçmenlerle konuşma becerilerini nasıl şekillendirdiğini anlamay1 da gerektirir.

Günümüzde bu pazarlama faaliyetleri genellikle reklam ajansları aracıllğı ile profesyonel olarak yürütülmektedir. Siyasal seçim sürecinde kararsız seçmenin oy verme davranışı üzerinde etkili olmaya çalışmak oldukça önemlidir. Siyasal reklamcılıkta bir reklam filminin seçimi kazandırabileceği fikrini ortaya atmak doğru değildir. Ancak siyasal reklamlar kararsız seçmenin davranışları üzerinde oldukça etkili olmaktadır. Kararsız seçmenin oylarının kazanılması bazen seçim sonuçlarını da olumlu yönde etkileyebilir. Siyasal reklamcılık uygulamaları bu noktada daha çok önem kazanmaktadır.

Siyasal reklamcılıkta hitap edilecek toplumun kültürel yapısı hakkında bilgi sahibi olmak ve bu bilgiler 1şığında stratejiler belirlemek hedef kitlenin seçim sürecindeki oy verme işlevi üzerindeki etkisini arttırmakta önemli rol oynamaktadır (Çaha,2008:2).

\section{Kültür ve Siyasal Kültür}

Kültür tanımı, insanın insan tarafından ortaya çıkarılmış ve geliştirilmiş olan çevresini ifade eder. Hofstede kültürü; bir grup insanı diğerlerinden ayıran zihinsel programlama olarak tanımlamaktadır (1994: 52). Maddi ve manevi olmak üzere iki kültür çeşidi vardır. Bazı sosyologlar maddi kültüre medeniyet ismini de vermektedirler. Maddi kültür yapıları, teknikleri, yolları ve araçlarımız gibi gözle görülür maddi unsurlardan oluşan kendi eserimizi ifade etmektedir. Manevi kültür de, bir milletin yapı taşlarını oluşturan ve kimliğini belirleyen ahlaki değer unsurlarından (yani örfler, adetler, kolektif davranışlar ve tutumlardan) oluşan bir bütündür (Bilgiseven, 1995:15). Dolayısıyla kültür gelenekler aracılığıyla yaşatılan, adetler üreten, toplumsal sürekliliği sağlayan, geçmişten günümüze kalan mirastır. Bunun yanı sıra her gelenek, bir önceki kültürel uygulamalar yorumlanarak, güncelle bağlantılandırılarak ve gelecek de göz önüne alınarak düzenlenip yaşatılır. Bu nedenle kültür, birlikte düşünme, örgütlenme ve bir arada yaşamanın yolu haline gelir (Kartarı, 2014: 29).

Siyasal kültür kavramı ise, toplumun yapı taşları içerisinde siyaset ve kültür alanları arasındaki bağlantıyı kurmaya, siyasetin kültür üzerindeki etkisini saptamaya çalışır (Burke, 2006:147). Kültürün siyaset üzerinde ne kadar belirleyici olduğu, toplumdaki bireylerin tutumlarının kültürel unsurlarla olan ilişkisi, bu ilişsinin oy verme davranışı üzerindeki etkileri siyasal kültür kavramını ifade etmektedir. Bir toplumu oluşturan bireylerin siyasal düşünceleri, tutumları, inanç, duygu ve değerlerinin oluşturduğu yapı 'siyasal kültür' olarak adlandırılmaktadır. Süreç içinde, toplumsal, sosyal, ekonomik ve siyasal alanda gerçekleşen değişimler, siyasal kültürün yapısını; siyasal kültürün yapısı da, toplumsal, ekonomik ve siyasal yaşamdaki değişmelere neden olmaktadır. Bu durumda siyasal kültürün araştırılması, toplumsal değişmeyi, bireylerin siyasal yapıyla ilişki kurma biçimlerini, siyasal yapının nasıl oluştuğunun anlaşılabilmesi için bizlere yol gösterici olmaktadır (Turan,2007:437). Diğer taraftan siyasal kültür kavramı, herhangi bir toplumda politik davranışı ortaya koyan ve yönlendiren tutumların, duyguların ve 
bilişlerin sadece rastgele bileşenler olmadığını aynı zamanda birbirine uyan ve karşılıklı olarak birbirini güçlendirici uyumlu kalıpları temsil ettiğini varsayar (W. Pye, 1969:7).

Siyasal kültür toplumun değer, inanç, yarg1, ahlak, örf ve adetlerinden etkilenmektedir. Toplumlarda düşünce sistemine göre siyasal fikirler ortaya çıkmaktadır. Her toplum kendi içinde kendi değerlerine hâkim siyasi görüşler barındırmaktadır. Bir toplumun tarihinde yaşanan siyasal olaylar o toplumun siyasal kültürünü anlamakta bizlere yol gösterici olmaktadır.

Siyasal kültür toplumsal kültürle paralel bir şekilde yol almaktadır. Toplumsal kültürdeki düşünceler sisteminden etkilendiği gibi bu düşünceler sistemine zit bir siyasal kültür oluşması beklenemez. Toplumlarda var olan siyasal kültür yöneticilere, siyasal ve ekonomik hayatın nasıl yönetileceği, toplumun ihtiyaçları ve bu ihtiyaçların karşılanmasında kullanılacak yollar hakkında bilgi verir. Toplumdaki egemen ideoloji toplumun siyasal kültürünün en belirleyici anahtarıdır.

\section{Siyasal Reklam ve Kültür İlişkisi}

Toplumları oluşturan yapı taşlarından biri de kültürdür. Kültür toplumlarda geçmişten gelecek kuşaklara aktarılmakta ve böylece toplumu oluşturan dinamiklerin korunması amaçlanmaktadır. Toplumlar kültürel kimliklerinin oluşmasını, muhafaza edilmesini ve gelecek kuşaklara aktarılmasını yaşanılan her çağda önemsemişlerdir. Kültürün korunması ve aktarılması için seçtikleri iletişim yöntemleri ise oldukça önemlidir. Kültür öğeleri bazen bir masalda, bazen bir türküde bazen de bir atasözünde karşımıza çıkmaktadır. İletişim gerek sözlü gerek yazılı halde olsun kültürümüzün oluşmasında ve iletilmesinde oldukça önemlidir. Kültür içinde bulunduğu hayat şartlarından etkilenmektedir. Teknolojinin ilerlemesiyle kültür olgusu üzerinde de birçok değişim yaşanmaktadır. Kültürün aktarılmasında da teknoloji günümüzde önemli bir yer oynamaktadır.

Özellikle kapitalizmin gelişmesiyle ardından yaşanan teknolojik gelişmelerle birlikte toplumlarda kitle kültürünün ortaya çıktığı görülmüştür. Kitle kültürü kitle üretimi yapan bir endüstriyel yapının yarattığı maddi yaşamı gerçekleştirme ve bu gerçekleştirmenin bilişsel ve düşünsel biçimidir. $\mathrm{Bu}$ bağlamda kitle kültürü seri üretimin sonuçlarından biridir ve kitle toplumundan önce ortaya çıkmamıştır. Kitle toplumu üzerine de inşa edilmemiştir. Kitle toplumunun ticarileşmesidir. Kapitalist toplumlarda kitle kültürü ticaridir. Aslında bu kültür mümkünse en geniş insan kitlesine satılan mal ve düşüncedir (Erdoğan ve Alemdar, 2011:41).

Teknolojinin gelişmesi her alanda olduğu gibi siyaset yapma biçim ve anlayışında da günden güne farklılıklara yol açmaktadır. Bu açıdan ele alındığında siyasal iletişim sürecinde kültürel değerlerin önemi hem seçmen hem de seçilenler için önemli bir unsurdur. Kültürel değerlere sahip bir siyasal partinin toplum gözünde olumlu biz izlenim kazanması siyasal reklamcılıkta da kültürel değerlere seslenen projelerin oluşmasına sebep olmuştur.

Toplumdaki mevcut kültür, insanların karar alma süreçlerinde oldukça etkilidir. Bu durum siyaset olgusunu da etkilemektedir. Demokrasiyle yönetilen ülkelerde toplumdaki egemen kültür, siyasete de yön vermektedir. Bu önemin farkında olan siyasal partiler seçmenler üzerinde etkili olmak için o toplumun kültürel öğelerini kullanmaktadırlar. Bunu yaparken de siyasal reklamcılık çalışmalarından faydalanmaktadırlar. Siyasal reklamcılıkta hedef kitle ile kurulan bağı güçlendirmek hedef kitlenin hafizasında olumlu bir yer edinmek için topluma hitap eden ahlaki değerler göz önüne alınmaktadır. Toplumun içinde yaşadığı kültürel öğelerin tespiti yapılmalı kültürel değerler doğrultusunda mesajlar hedef kitleye ulaştırılmalıdır.

Siyaset yapanlar toplumla her an iletişim halinde olmak zorundadırlar. Bu iletişimin sağlıklı bir şekilde kurulmasında o toplumun yapı taşlarının, kültürel değerlerinin iyi biliniyor ve bu değerler üzerinden kuruluyor olmasıyla sağlanır. Bunun bilincinde olan siyasal partiler de seçim dönemlerinde gerçekleştirdikleri iletişim çalışmalarından biri olan siyasal reklamcılıkta toplumun kültürel değerlerine hitap ediyor olmayı amaçlamaktadırlar. 


\section{Geert Hofstede’nın Kültüir Boyutları Hakkında Çalışmaları}

Geert Hofstede, kültür konusunu ele aldığı çalışmalarında toplumdaki kültürel farklılıkların temel sorunların belirleyici bir unsuru olduğu üzerine yoğunlaşmıştır. Toplumlardaki çatışma veya birleşme durumlarının tetikleyicisi kültürel bağlardır. Toplumların ekonomik evrimlerinin kültürün üzerindeki etkilerine değinmiştir. Ayrıca Hofstede kültürel evrimlerin toplumların modernleşme dereceleri olduğunu tespit etmiştir. Kültürün toplumlar için bir miras olduğunu çalışmalarında hep savunmuştur. Bu mirasın genetik transfer yoluyla değil insanların doğru yerde doğru zamanda bulunmasıyla iletilen bir süreç olduğunu ileri sürmüştür (Hofstede,2003:5).

Hofstede 1980'lerden itibaren kültür alanında yaptı̆̆ çalışmaları günümüze dek güncelleyerek, kültür alanında yapılacak birçok araştırmaya referans olmuştur.

Hofstede çalışmalarında kültürü beş farklı boyutta ele almıştır. Bunlar:

1) Güç Mesafesi

2) Bireycilik/toplumculuk

3) Belirsizlikten Kaçınma

4) Erillik/Dişilik

5) Uzun vadeye/kısa vadeye yönelim şeklindedir.

$\mathrm{Bu}$ beş boyuta ek olarak Holsftede Türkiye'yi değerlendirirken 6. Boyut olarak pragmatizm/ normativizm boyutunu da eklemiştir.

'Güç Mesafesi' boyutunda, toplumlarda, kurumlarda ve işletmelerden güç ve hiyerarşiye dayanan eşitsizliğin olumlu ve olumsuz etkileri, toplumda yer alan statü farklarının toplumu ne kadar yönlendirdiği dikkate alınmıştır. Güç aralığı fazla olan ülkelerde güç dağılımında ve bu durumun etkisiyle ortaya çıkan firsat eşitsizliğinin dengesizliği kabul görmektedir. Bu kültürel boyutta statü, kademe, unvan, alt üst ilişkisi pozisyonları oldukça önemli yer kaplamaktadır. Isşçi ve işveren, yönetici ve yönetilen ayrımları fazlaca hissedilmektedir. Bu mesafenin korunmasında önemli bir unsurdur. Güç aralığının dar olduğu toplumlarda ise bireylerin birbirlerine ulaşmaları daha kolaydır. Yönetenlerin karar alma süreçlerinde yönetilenlerin söz hakları vardır. Fırsat elde etme ve ödüllendirme gibi süreçlerde ise eşitsizlik daha az görülmektedir.

'Bireycilik/toplumculuk' boyutu incelendiğinde ise temelde bireyin kendini nasıl tanımladığı görülür. Bireysel toplumlarda kişi kendini toplumdan bağımsız bir birey olarak tanımlamaktayken; toplumcu kültürün hâkim olduğu toplumlarda ise birey kendini toplumun bir parçası olarak görmektedir. Toplumcu kültürün hâkim olduğu toplumlarda bireyin kendi çıkarlarından ziyade toplumun çıkarları daha önemlidir. Burada birey toplumun kendinden beklediği rollere cevap verme zorunluluğu hisseder. Bireyci toplumlarda ise birey kendi çıkarlarını her daim ön planda tutmaktadır. Toplumun başarısı değil bireysel başarının önemli olduğu düşünülür.

'Belirsizlikten kaçma' boyutu, insanların yasalar, örf ve adetler töreler gibi toplumsal düzeni sağlayan kuralları ne derece isteyip önemsedikleriyle ilgilidir. Dolayısıyla bu boyut kontrol duygusunun baskın olmasıyla ilgilidir. Belirsizlikten kaçışın yüksek olduğu toplumlarda bireyler gelecekte karşılaşabilecekleri sorunlara ve tehlikelere karşı en az seviyede zarar görmeleri için yapacaklarının bilincinde olmak isterler. Kendilerini güvence altında tutmak, nerede nasıl davranacağının bilincinde olma rahatlığını yaşamak isteyen toplumlarda hakim bir kültürel boyuttur.

'Erillik/dişilik' boyutu ise toplumun erkeksi değerler ve dişilik değerleri üzerinde şekillenmesidir. Erkeklik boyutu yüksek toplumlarda; para güç, rekabet, performans ön plandayken; dişil toplumlarda, yaşam kalitesindeki artış, toplumun iyileştirilmesi, doğanın ve hayvanların korunması, temiz bir çevre sağlanması, saygılı bireyler yetiştirilmesi, dayanışma ve yardımlaşma gibi kavramlar önde gelmekte ve önemsenmektedir. 
Zamanın dikkate alındığı boyut olan 'Uzun vadeye/kısa vadeye yönelim' boyutunda bireylerin gelecek odaklı ya da geçmiş odaklı yaklaşımlarına dayanmaktadır. Geçmişe dayalı bakış açısına sahip toplumların daha geleneksel tiplerden oluştuğu, geçmişi korumayı amaçladığı gelenek görenek örf adet gibi unsurları yaşattığı görülmektedir. Ayrıca geleceğe yönelik bakış açısına sahip toplumların daha çok toplumsal değişmeyi ve teknolojik ilerlemeyi amaçladıkları görülmektedir (Holfstede,2003:25).

\section{Amaç ve Yöntem}

Çalışmanın temel amac1; Sosyolog Geert Hofstede'nin çalışması olan kültürel boyutlar çerçevesinde Türkiye'de siyasal seçim reklamlarını analiz ederek reklam filmlerinde kültürel boyutların varlığının vurgulanıp vurgulanmadığını ya da ne seviyede vurgulandığını belirlemektir. $\mathrm{Bu}$ sayede siyasal reklamlar hazırlanırken kültürel boyutlardan ne kadar faydalanıldığ boyutlara daha sık vurgu yapıldığını tespit etmek amaçlanmıştır. Bu çalışmada reklam filmi metninin ve reklamda kullanılan görsellerin kültürel boyutlar çerçevesinde incelenmesi temel alınmıştır. Siyasal reklamların içeriklerinin kültürel boyutlarının analizinde Hofstede'nin 'Kültürel Boyutları' detaylı olarak alt kategorilerle ele alınmaktadır. Bu amaç bağlamında 24 Haziran genel seçimlerinde Adalet ve Kalkınma Partisi için hazırlanan 'Zümrüd-ü Anka' seçim reklamı incelenmiştir. Tek bir dönem ve tek bir reklamın ele alınması çalışmanın sınırlılığını oluşturmaktadır. Hofstede'nin üzerinde çalıştığı kültürel boyutların literatür kısmında açıklanan; 'güç aralığı, bireycilik/kolektivizm, erillik/dişilik, belirsizlikten kaçınma, pragmatizm/normativizm ve uzun vadeye- kısa vadeye yönelim' şeklinde sınıflandırdığı kültürel boyutlar incelenmiştir. Reklam filmlerinde, kültürel boyutların kullanımını irdelemek amacıyla, her kültürel boyutun içeriğine uygun hangi vurguların nasıl yapıldığı sorgulanarak içerik analizi yöntemi kullanılmıştır. İcerik analizi yapılırken reklam metninde yer alan alan ifadeler Hofstede'nin çalışmasında gruplandırdığı kültürel boyutlara göre yorumlandırılmıştır.

$\mathrm{Bu}$ araştırmada seçim dönemleri için hazırlanan siyasal seçim kampanyalarında yer alan reklam filmleri içerisinden seçilen 24 Haziran milletvekili genel seçimlerinde seçmene sunulan Adalet ve Kalkınma Partisi'nin 'Zümrüd-ü Anka' isimli reklam filmi incelenmiștir.

Siyasal iletişim, bu çalışmada da sözü edilen ve tarih boyunca kültürün belirleyici faktörleri konusunda üzerinde çalış1lan birçok kuramdan faydalanabilecek ve stratejilerini söz konusu kuramlara göre belirleyebilecektir. Siyasal kampanyalar sürecinde seçmene mesajlar iletilirken, mesajların kodlanmasında Hofstede'nin kültürel boyutları çalışması ele alınarak 24 Haziran milletvekili genel seçim döneminde kullanılan Zümrüd-ü Anka siyasal reklam filmi içerik analizi yoluyla incelenmiştir.

Ayrıca çalışmada ele alınan Adalet ve Kalkınma Partisi'nin 24 Haziran 2018 milletvekili genel seçimleri için hazırladığı Zümrüd-ü Anka isimli siyasal seçim reklamı çalışmanın örneklemini oluşturmaktadır.

\section{Siyasal Reklamlarda Kültürel Boyutlara Yapılan Vurgular}

Çalışmada yer alan siyasal reklam filminin incelenen kültürel boyutlara göre kabul görme gerekçeleri aşağıda belirtilmiştir.

\section{Güç Aralığ1 Boyutu:}

İncelenen reklam filminde güç aralı̆̆ boyutu, merkezi otoritenin reklamda halk ile arasındaki mesafeyle nasıl konumlandırıldığı şekline göre yapılmıştır. Merkezi otoriteye yapılan vurguyla, merkezi otoritenin halkla arasındaki bağın nasıl aktarıldığı tespit edilmeye çalışılmıştır. Merkezi otoriteye yapılan olumlu vurguyla, burada kastedilen otorite yeri geldiğinde devlet başkanları yeri geldiğinde anne baba, grup lideri, kurum yöneticisi v.b. olabilmektedir. Reklam filminde ise merkezi otorite siyasal partinin egemenliği yani iktidar olarak kullanılmıştır. Merkezi otoritenin kurallarına, talimatlarına gönüllü olarak razı olma durumu olumlu bir vurgu şeklidir. 
Aynı şekilde olumlu vurgu siyasi iktidar tarafindan yönetilmeye razı olma bu durumdan şikâyetçi olmama söylemleriyle de vurgulanmıştır. Toplumda bireylerin kendi seçtikleri başka bir gücün, kendileri adına karar verme yetkisini kabul ediyor olmaları merkezi otoritenin varlığına yapılan olumlu vurgu olarak ele alınabilir.

\section{Bireycilik/Kolektivizm (Kolektivizm) Boyutu:}

Siyasal partilerin reklam filminde sadece kendi seçmenine mi seslendiği yoksa tüm ülkenin vatandaşlarına $\mathrm{m} ı$ seslendiği bu kültürel boyut için oldukça belirleyicidir. Siyasal partilerin sadece kendi seçmenin refahını $\mathrm{m} 1$ düşündükleri yoksa içinde bulundukları grubun, ailenin refahını ve huzurunu mu istediği sorgulanmıştır. Aynı zamanda siyasal partilerin kendilerini toplum içinde konumlandırdığı yer, bu kültürel boyutun vurgusunda önemlidir. Siyasal partiler kendilerini toplumun içinde toplum için çalışan kurumlar olarak $\mathrm{m} 1$ gösteriyor ya da toplumun dışında toplumdan üstün bir gücü mü ifade ediyor? Bu konumlandırmanın tespiti amaçlanmıştır. Reklamlarda yapılan biz vurgusu, beraberlik vurgusu, minnet duygusu Bireycilik/Kolektivizm (Kolektivizm) boyutunu vurgulayan unsurlardandır.

\section{Erillik/Dişilik (Dişilik) Kültürel Boyutuna Yapılan Vurgu:}

Toplumun erillik /dişilik özelliklerinin incelendiği bir boyuttur. Siyasal reklamlarda siyasal partinin ve seçmen kitlesinin; sosyal bir birey olması, yardımlaşmaya vurgu yapılması, çevre bilincinin oluşması, çevrenin ve hayvanların korunması, dayanışmaya önem verilmesi gibi dişil karaktere ait özelliklerin vurgulandığı söylemler analiz edilmelidir. Toplumdaki güç unsuruna, savaşçılığa, rekabet ve para gibi eril söylemlere dikkat edilmiştir. Reklamda varolan bu tarz söylemlerde erillik kültürel boyutunu temsil etmektedir. Siyasal reklamda erillik/ dişilik kültürel boyutu incelenirken sadece erillik unsurların ya da sadece dişilik unsurlarının yapılmasını beklemek yanlış olacaktır. Toplumda her iki kültürel boyutun var olduğu gibi reklamlarda da bu kültürel boyutlara aynı anda vurgu yapılabilmektedir.

\section{Belirsizlikten Kaçınma Kültürel Boyutuna Yapılan Vurgu:}

Bu kültürel boyutta seçmenin kendini güvende hissettiği, daha önce denediği kendisi hakkında bilgisi olan durumları tercih etmesi durumu dikkate alınmıştır. Seçmenin daha önce denediği yani denenmiş adayı tercih etmesi reklamda vurgulanıyorsa, bu belirsiz durumlardan kaçınma boyutunun göstergesi olarak kabul edilmiştir. İktidar partileri bu kültürel boyuttan son derece faydalanmaktadırlar. Özellikle seçimden önce yaptıkları çalışmaları geleceğe referans olarak göstermektedir. Seçmene biz çalıştık siz de bunu gördünüz mesajını vermektedirler. Muhalefet partileri de bu kültürel boyutu iktidar partisinde geçmişte yaşanan olumsuz durumları tekrar göz önüne çıkartarak kullanmaktadır. İktidar partisinin geçmişteki başarısızlığının gelecekte de gerçekleşebileceğini vurgulamaktadırlar.

Pragmatizm - Toplumsal Değişim Kültürel Boyutuna Yapılan Vurgu:

Toplumsal değişimin olumlu yönde olacağının, yapılacak çalışmaların toplumu ileri taşıyacağının vurgusu yapıldığında; pragmatizm/toplumsal değişim kültürel boyutuna yapılan vurgu ortaya konulmaktadır. Bu kültürel boyut temsil edilirken genellikle; gelecek aydınlık güneşli günlerin varlığından, çağı yakalamaktan, ekonomik refahtaki artıştan, çocuklarımızın geleceğindeki güzelliklerden bahsedilir. Tüm bunlar reklam filminde konuşan oyuncular, hareketli görüntüler veya dış ses aracılığı ile en az bir kez yapılmışsa pragmatizme vurgu yapıldığı kabul edilmiştir.

Uzun Vadeye-Kisa Vadeye Yönelim Boyutu:

Seçim reklamlarındaki vaatlerin içeriği ele alınmıştır. Seçmene sunulan vaatlerin seçmeni ne kadar ileriye taşıyacağı, seçmenin gelecek kaygılarına ne derece çözüm sunduğu tespit edilmeye çalışılmıştır. Seçim vaatlerinin kısa sürede gerçekleşeceğinin iddiası da seçmendeki gelecek kaygısı için bir cevap niteliği taşımaktadır. Reklam filminde özellikle gelecek nesiller için sunulacak 
imkanları ortaya koymak, geçmiş ile gelecek arasında yapılan karşılaştırmaların ele alınması anlamina gelmektedir.

\section{Bulgular ve Yorumlar}

Çalışmanın bu bölümünde yukarıdaki belirtilen kıstaslara göre araştırma amacına yönelik olarak seçilen seçim reklam filminde görsel/sözsel vurguların hangi kültür boyutları altında kümelendikleri incelenmiş ve bu incelemeler sonucunda ulaşılan bilgiler eşliğinde bulgular analiz edilmiştir.

\section{Güç Mesafesi Kültürel Boyutuna Yapılan Vurgu (Merkezi Otoriteye Yapılan Vurgu)}

Reklamin son sahnesinde sözel olarak vurgulanmasa da görsel olarak Zümrüd-ü Anka kuşunun Adalet ve Kalkınma Partisi iktidarı boyunca yapılan projeler etrafinda döndüğü görülmektedir. Zümrüd-ü Anka kuşunun Recep Tayyip Erdoğan'ın işareti ile gökyüzünde Adalet ve Kalkınma Partisi sloganına dönüşmesi, sloganın gökyüzünde belirmesi, Recep Tayyip Erdoğan'ın eliyle onu işaret etmesi aydınlık bir geleceğe ve bu geleceğin Recep Tayyip Erdoğan'ın iktidarıyla beraber gerçekleşeceğine vurgu yapmaktadır. Reklam filminin Recep Tayyip Erdoğan'ın sesiyle canlandırılması ve son sahnede görülen resmi kıyafetler ise otoriter bir güç unsurunu vurgulamaktadır.

Reklam filminde merkezi otorite ile halk arasındaki mesafeye ayrı bir vurgu yapılmamakta aksine "biz" vurgusuyla bir bütünlük oluşturmak istenilmiştir. Halkın merkezi otorite ile iletişiminin, kültürel boyutlar açısından güç mesafesinin yakın olduğu tespiti yapılmıştır. Yapılmış ve yapılacak bütün çalışmalarda halkın gücüne ihtiyaç duyulduğu vurgulanmıştır. Bu da merkezi otoritenin gücünü halktan aldığının bir göstergesidir.

Dolayısıyla başarma eylemini iktidarın değil, Türkiye'nin gerçekleştireceği vurgulanmıştır. Bunlarla beraber merkezi otorite halktan kopuk bir konuma yerleştirilmemiştir. Böylece iktidar olarak halkla bir bütün oluşturmak amaçlanmıştır. 'Halktan biriyiz halkımız için çalışıyoruz'. 'Halkın desteği ile var oluyoruz' söylemleri de merkezi otoritenin güç mesafesi boyutu açısından halktan uzak olmadığının göstergesi niteliğindedir.

\section{Belirsizlikten Kaçınma Kültürel Boyutuna Yapılan Vurgu (Geçmişe referans, gelecek için garanti verme)}

$\mathrm{Bu}$ kültürel boyut için seçmenin daha önceden tanıdığı, Türk tarihinde yer edinmiş, yaptıkları hizmetlerle, örnek davranışlarıyla toplumu her zaman ileriye taşımış kişilerden referans alınmaktadır. Alparslan, Melikşah, Gazi Osman Paşa, Fatih Sultan Mehmet, Kanuni Sultan Süleyman, II. Abdülhamid Han, Mustafa Kemal Atatürk gibi Türk tarihinde yer edinmiş kişiler referans gösterilmiş ve gelecek için bu kişilerin kanından gelindiğinin, başarmak için gereken gücün geçmişimizde var olduğu vurgulanmıştır. "Geçmişini bil ki geleceğe 1şık olasın" söylemi geçmiş başarıların geleceğe referans olacağı niteliğindedir. "Cumhuriyet'inin ilelebet yaşayacağının resmisin" söylemiyle Mustafa Kemal Atatürk'ün geçmişte yaptıklarını referans göstererek; gücün geçmişten alındığı vurgulanmış ve gelecek için başarı garantisi verilmiştir. Reklamın son sahnesinde doğan güneşe odaklanılması, 24 Haziran seçimlerini Adalet ve Kalkınma Partisi'nin kazanması durumunda yeni ve aydınlık bir dönemin başlayacağının haberini de vermektedir. vurgusu)

Bireycilik/Kolektivizm Kültürel Boyutuna Yapılan Vurgu (Aile, grup vb. 'biz'

Reklam filminin ilk cümlesi "Ey Türkiye!” şeklindedir. Dolayısıyla reklamın ilk dakikalarıyla bireysellikten kaçınan, toplumu bir bütün olarak; Türkiye olarak ele alan 'biz' vurgusunun yapıldığı bir siyasal birlik mesajı verilmiştir. Reklam Türk tarihini bir bütün olarak ele almıştır. Geçmişten günümüze yapılan tüm faaliyetleri, elde edilmiş tüm kazanımları bir aile olarak 
biz başardık vurgusu yapılmıştır. "Geçmişini bil ki geleceğe 1ş1k olasın cümlesiyle gene gelecek için uğraşacak, gelecekte iyi şeyler başaracak olanın sadece bir birey değil toplum olduğu vurgulanmıştır. Güzel bir geleceğin birlik olmaktan, Türkiye olmaktan geçtiği vurgulanmıştır. Seçim reklamı boyunca Adalet ve Kalkınma Partisi önderi Recep Tayyip Erdoğan, sadece kendi seçmenine değil tüm ülkeyi kapsayacak seçmene ve değerlere seslenmiştir. Böylelikle sadece bir grubun değil tüm Türkiye'nin Cumhurbaşkanı olmak istediğini ifade etmek istemiştir. Reklam filminde ayrıştıran, ötekileştiren ve dışlayan unsurlara yer verilmemiştir. Tüm bunlar Holfstede'nin kültürel boyutlarından bireycilik/kolektivizm boyutu içinde ele alınabilir.

\section{Erillik/Dişilik Kültürel Boyutuna Yapılan Vurgu (Duygulara, yardımlaşmaya vurgu)}

İncelenen reklam filminde topluma dişilik özelliği gösteren, saygıllı, duygusal, yardımsever sıfatları yüklenmiştir. $\mathrm{Bu}$ sıfatlarla toplumdaki dişilik duygularına seslenilmiş ve duyguları harekete geçirmek amaçlanmıştır. "Ey Türkiye! Bak Ufuktaki yola, tarihini, atalarını, kardeşini kolla. Şimdi elini uzat başlasın en güçlü devir!" söylemleri ile birlik ve beraberliğe, yardımlaşma duygusuna vurgu yapılmıştır. Topluma savaşçı, k1lıç tutan, güçlü, yenilmez, kudretli, nefer, siper, kollayıcı gibi erillik sıfatları da yüklenmiştir. Bu sıfatlar ile ise toplumdaki erillik duygularına seslenilmiş, bu duyguları açığa çıkarmak amaçlanmıştır. Bunlar ile Hofstede'nin kültürel boyutlarından erillik/ dişilik boyutuna vurgu yapılmaktadır. Toplumdaki erillik ve dişilik özelliklerine aynı derecede seslenilmiş topluma sadece eril ya da sadece dişil nitelikler yüklenilmemiştir.

Pragmatizm/Toplumsal Değişime Vurgu (Toplumda bir şeylerin olumlu yönde değişeceğine, eskisi gibi olmayacağına yapılan vurgu)

Reklam filminde "Kaderimiz bu söylemini geride bırakarak" ifadesi yaşanan olumsuzlukların kaderimiz deyip kabullenilmemesi; bu olumsuzlukların ancak kabul görmediğinde, tepki gösterildiğinde olumlu yönde değişeceğine vurgu yapılmaktadır. Reklamın sonlarına doğru "Şimdi elini uzat! Başlasın en güçlü devir" söyleminde ise artık hiçbir şeyin eskisi gibi olmayacağına, Türk tarihinde yaşanılan başarılar referans alınarak, elde edilen bilgi birikimiyle artık daha güçlü olunacağına ve yaşanılan en güçlü devir olacağına vurgu yapılmaktadır. Yenilenmek, şahlanmak, dörtnala koşmak ifadeleri ise gene geleceğin iyi olacağına dair yapılan vurgulardır. Reklamın sonunda yazılı görsel ve sözlü olarak vurgulanan “Türkiye Vakti!” sloganı da Türkiye'nin geleceği için olumlu anlamda yaşanılacak değişimlere yapılan vurgudur. Tüm bunlar Holfsede'nin kültürel boyutlarından Pragmatizm boyutunun içinde sınıflandırılabilir.

\section{Kısa Döneme- Uzun Döneme Yönelik Olma (Zevk ve haz odaklı yaşama, hayattan keyif almaya vurgu)}

24 Haziran Seçimleri için hazırlanan reklam filminde, "Sonsuzlukta yankılanan yolun başındasın. Senin kudretinin ulaştığı yere onların hayalleri dahi ulaşamasın. Zaferi kendine vaat edesin. Cumhuriyet'inin ilelebet yaşayacağın resmisin. Başlasın en güçlü devir!, Birlik, bereket, bolluk için" söylemleri yer almaktadır. Bu söylemlerle Türk halkının hak ettiği yere vurgu yapılmaktadır ve Türk halkının gelecek güzel günleri hak ettiği vurgulanmaktadır. Bununla birlikte, Türk tarihindeki büyük başarılardan bahsedilmekte ve ülkenin eski gücüne tekrar kavuşabileceği mesajı verilmektedir. Gelecek güzel günlerin Adalet ve Kalkınma Partisi ve Recep Tayyip Erdoğan iktidarı ile beraber gerçekleşecek bir yükselişin betimlemesi yapılmaktadır. Tüm bunlar gelecekte yaşamdan haz ve keyif almaya ve başarılı olmaya yapılan vurgulardır. Bu söylemlerin hepsi yapılan seçim faaliyetlerinin, seçim çalışmalarının adeta yeni bir devir yaratacak olduğu ve uzun süreli yatırımlar anlamına geldiği böylece gelecek vizyonunun uzun vadeye yayıldığı da vurgulamaktadır. Bu vurgular ise Holfstede'nin kültürel boyutlarından kısa döneme-uzun döneme yönelik olma boyutu içerisinde sınıflandırılabilir. 


\section{Sonuç}

Siyasal iletişim kavramı siyasi partilerin ya da siyasi adayların hedef kitleleriyle onların ikna edilmesi üzerine aralarında kurdukları iletişim anlamını taşımaktadır. Siyasal reklamcılığın önem kazanmasıyla birlikte siyasal iletişim, siyasetçilerin kendi aralarında girdikleri bir söylem mücadelesi şeklini almıştır. Siyasal reklamcılık günümüzde siyasetçiler tarafindan sadece hedef kitleye ulaşma aracı olarak değil, rakiplerinden daha etkili ve ileride olmak için de kullanılmaktadır. Seçim süreci siyasi partiler, markalar, kurumlar, yöneticiler için sadece seçilmekten ve seçim sonuçlarından ibaret değildir. Seçim süreci ve sonucu her aday için bir prestij meselesidir. Seçim öncesi, seçim süreci ve seçim sonrasında iletișim faaliyetleri titizlikle sürdürülmelidir. Doğal olarak insanlar seçim yapacakları konuda bilgi sahibi olmak isterler. Dolasıyla seçmenleri bu konuda bilgilendirmek adaylar için en önemli unsurlardan biridir. Seçmenler seçecekleri tarafları tanımak ve kendi çıkarları doğrultusunda seçim yapmak eğilimindedir. Seçim yapacakları adaylar, konular hakkında kafalarında oluşturdukları imaj onları yönlendirir. İşte bu imajı yönetmek adına siyasal seçim sürecinde adaylar ya da partiler birçok seçim kampanyası yürütmektedirler. Siyasal seçimler tarih boyunca ilk uygulamalarından bu yana siyasal reklamcılık uygulamaları, kullanılan çeşitli ortamlar, kampanyalar ve stratejik davranış biçimiyle varlığını sürdürmüştür. Dünyada 1950'li yıllarda televizyon yayıncıllğının hayata girmesi, televizyon aracıllğıyla verilen birçok ileti ile seçmenin oy verme davranışı üzerinde etkili olabileceğinin kabul görmesi siyasal reklamları doğurmuştur. Siyasal parti aktörlerinin ya da adayların, toplumda var olan o anki iklime, toplumun karakterine uygun stratejiler belirleyerek kararsız seçmenlerin oy verme davranışı üzerinde etkili olma çabasına giriştikleri bilinmektedir. $\mathrm{Bu}$ bağlamda iletişim faaliyetlerinden reklamları kullanma fikri de televizyonun yaygınlaşması ve izleme oranlarındaki artışla birlikte daha da kabul görmüştür. Böylelikle reklam belirgin bir şekilde bir siyasal iletişim aracı halini almış, siyasal seçim çalışmalarında sıklıkla kullanılmaya başlanmıştır.

Yaşanılan tüm bu gelişmeler seçim sürecindeki sosyolojik yaklaşımların da gelişimini ve ele alınmasını desteklemektedir. Siyasi adaylar ya da partiler için toplumsal olgular seçim sürecinde anahtar niteliğindedir. Siyasal iletişim faaliyetleri bizlere, siyasal partilerin ya da adayların hitap ettikleri toplumların kültürel yapılarını gözeterek, toplumların kültürel kodlarından, yaşam biçimlerinden, maddi ya da soyut birikimlerinden ilham aldıklarını da göstermektedir.

Reklamın analizi sonucunda elde edilen bulgular, reklam metninde Hofstede'nin kültürel boyutlarının hepsine vurgu yapıldığını göstermiştir. Özellikle geleceğe yönelik olma, gelecek hakkında vaatler verme, gelecek günlerin geçmişten daha güzel olacağına fazlaca vurgu yapılmıştır. Bununla birlikte, Türk toplumunun birlik ve beraberliğe verdiği önem üzerinde durulmuştur. Toplumda bir bütünlük oluşturmak adına reklam filminde "Biz" vurgusu her cümlede geçmektedir. Yapılmış ve yapılacak olan her faaliyetin halkın desteği ile hayata geçirildiği, iktidarın gücünü halktan aldığı, iktidarın halk ile bir bütün olmak istediği v.b. mesajlar, toplumun birlik beraberlik duygusuna yapılan vurgulardır.

Ayrıca bir toplumu ayakta tutan dinamiklerin başında ortak bir kültüre sahip olmak gelmektedir. Bu kültür toplum tarafindan benimsenip gelecek kuşaklara aktarıldığında, toplum dinamikleri güçlenecek ve böylece yardımlaşma, birlik duygusu ülkeyi, ülkenin insanlarını sevme isteği artacaktır. İncelenen reklam filminde ortak kültür unsuruna dikkat çekildiği ve bu kültüre sahip çıkılacağı vurgusu görülmektedir. Dolayısıyla siyasal iletişim sürecinde seçmenin kültürel değerlerine sahip çıkıldığ 1 görülmektedir.

Seçmen kitlesi ülkeyi yönetecek zümrenin kendi kültürel değerleriyle bir bütün olduğunu görmek ister. Siyasal partilerin, desteğini istediği seçmenin hayat tarzını, ideolojik yaklaşımlarını, hayattan beklediklerini, sosyal ve ekonomik kaygılarını biliyor olması seçim sürecindeki vaatlerinin belirlenmesinde siyasal aktörlere, stratejistlere yol gösterici olmaktadır. Seçmen iktidarda olan kadroların kendiyle aynı görüşte olduğunu, kendi çıkarlarının önemsendiği fikrini de 
benimsemektedir. Kitleler ihtiyaçlarının karşılanmasını ister. Bu nedenle seçmenler kendiyle aynı görüşte olduğunu bildiği iktidarın kendi ihtiyaçlarını karşılayacağını düşünürler. Seçmenin isteklerinin yanında, adaylar ya da partiler de daha uzun yıllar iktidarda kalmayı ve hedeflerini gerçekleştirmeyi amaçlamaktadır. Seçen ve seçilen arasındaki bu karşılıklı ilişki ihtiyaçların giderilmesinden beslenmektedir. Böylece toplumlarda kendisiyle ortak kültür çevresinde yer alan siyasi gruplara duyulan yakınlık artmaktadır. Bu doğrultuda siyasal partiler seçim stratejilerinde kullandıkları dilde kültürel ögelere vurgu yapmayı tercih etmişlerdir. Bu bağlamda toplumdan uzak, erişilmez görülmek yerine; toplumla iç içe aynı kültürel değerlere sahip olduğunu vurgulamaktadırlar.

Siyasal iletişim sürecinde hedef kitlenin doğru tespit edilmesi ve hedef kitlenin yeterince tanınması durumunda verilecek mesajların tespiti kolaylaşır. Hedef kitleye göre siyasal seçim kampanyaları oluşturulur. 24 Haziran 2018 milletvekili genel seçimlerinde Adalet ve Kalkınma Partisi'nin 'Zümrüd-ü Anka' reklam filmiyle uyguladığı iletişim stratejisi bu yönde geliştirilmiştir. $\mathrm{Bu}$ reklam kampanyası ile verilmek istenilen mesaj, hedef kitlenin kültürel değerlerine göre analiz edilmiş ve bu doğrultuda şekillendirilmiştir. Toplumun inançlarına, geçmişten gelen bağlarına, geçmişine, sahip olduğu değerlere, gelecekte bulunmak istediği konuma vurgu yapılmıştır. Holfstede'nin kültürel değerler tablosuna göre analiz edilen reklam filminde oluşturulan her kategoriye ait yapılan vurgular tespit edilmiştir. Çalışmada ele alınan reklam filminin analizi sonucunda da siyasal iletişim sürecinde gerçekleştirilen iletişim faaliyetlerinin toplumun kültürel değerlerinin göz önüne alınarak planlandığı; ortak kültürel değerlerin, unsurların dikkatle seçilip siyasal söylemlerin bu doğrultuda hazırlandığı görülmüştür.

\section{Kaynakça}

Aziz, A. (2013). Siyasal İletişim (4. Bask1), Nobel Yayınları.

Bilgiseven, A.K. (1995). Genel Sosyoloji. Filiz Kitabevi.

Burke P.(2006). Kültür tarihi. (Çev. Mete Tunçay), İstanbul Bilgi Üniversitesi Yayınları.

Çaha, Ö.(2008). Türkiye'de Seçmen Davranışı ve Siyasi Partiler. Orion Kitabevi.

Erdoğan, İ ve Alemdar, K. (2011). Kültür ve İletişim.(3.Bask1), Erk Yayınları.

Fowler, E., Franklin, F., Michael M. And Travis.N. (2018). Political Advertising in The United States. Newyork: Routledge Taylor\& Francis Group, ISBN 13: 978-0-8133-4975-6 (pbk)

Geert, H. (2003). Culturesand Organizations: Intercultural Cooperation and Its Importance for Survival, Software of the Mind. Profile Books.

Greet H. and Robert, M. (2004). "Culture and Personality Revisited: Linking Traits And Dimensions Of Culture”, Cross-Cultural Research, 38, s.52-88.

Greet, H. (1993).“Cultural Constraints İn Management Theories”, The Academy of Management Executive, 7, 81-94.

Greet, H. (2001). "Culturel Consequences: Comparing Values, Behaviors, Institutions and Organizations across Nations", Thousand Oaks, CA: Sage published in the PRC as Vol. 10 in the Shanghai Foreign Language Education Press SFLEP Intercultural Communication Reference Series, s.244-289

Kartarı, A. (2014). Kültür, Farklıllk ve İletişim, (1. Bask1), İletişim Yayınları.

Kılıçaslan, E.Ç. (2013). İdeoloji ve Medya İlişkisi Siyasal İletişsim, Yayınlanmamış Yüksek Lisans Tezi, Hacettepe Üniversitesi, Sosyal Bilimler Enstitüsü. 
Köker, E.(1998) Politikanın İletişimi İletişimin Politikası, Vadi Yayınları.

Mutlu, E.(2014). İletişim Sözlüğ̈̈, Bilim-Sanat Yayınları.

Oktay, M.(2014). Demokratik Sürecin Sağlıklı İşleyişi Açısından Siyasal İletişimde Sosyal Sorumluluk Projesi, Marmara Üniversitesi, Marmara İletişim Dergisi 2/2, 75-90.

Schill D, Kirk R ve Jasperson A.E, (2017) Political Communication in Real Time. (1. Published), Newyork: Routledge Taylor\& Francis Group, ISBN: 978-1-138-94940-9 (hbk) ISBN: 9781-138-94941-6 (pbk) ISBN: 978-1-315-66908-3 (ebk)

Tokgöz, O. (2010). Seçimler, Siyasal Reklamlar ve Siyasal İletişim, İmge Kitabevi.

Tokgöz, O.(2008). Siyasal İletişimi Anlamak, İmge Kitabevi.

Turan, İ.(2007). Türkiye'de Siyasal Kültürün Oluşumu, Türkiye'de Politik değişim ve Modernleşme içinde, Alfa Akademi.

Uztuğ, F.(1994). Siyasal Marka Seçim Kampanyaları ve Aday Imajı, Mediacat Yayınları. 